\title{
Eulogising the Dead: A Systemic Functional Exploration of Tributes Delivered by Ghanaian Presidents
}

\author{
Mwinwelle Peter ${ }^{1}$, Duah Ishmael $^{2}$ and Ernest Mensah Solomon ${ }^{3}$ \\ 1,2,3 Department of General Studies, Koforidua Technical University, Post Office Box KF 981, Koforidua, Ghana \\ ${ }^{1}$ Correspondence: pmwinwelle@gmail.com
}

\begin{abstract}
Presidents are considered as caring and sensitive fathers of their nations whose words of condolences are usually needed in times of grief. One medium through which they express their condolences is through the delivery of tributes to eulogize the dead and sympathize with bereaved families. There is therefore the need to examine how presidents employ the faculties of language to eulogize the dead in their tributes. Premised on the transitivity framework postulated by Halliday and Matthiessen, the present study investigates the use of transitivity patterns in Ghanaian presidential tributes to unearth various experiences and also unveil the implicit relationships that exist between politicians and traditional rulers. The sample for the study is composed of four tributes delivered by Akuffo Addo, Mahama, Kufour and Rawlings to the late Queen Mother of the Ashanti Kingdom, Nana Afia Kobi Serwaa Apem II. The data were manually coded using the consensual coding strategy. The results indicate a preponderant use of relational processes to identify the unique qualities possessed by the late Queen Mother which further unveil the varied relationships between her and the presidents. Other process types such as material, mental, verbal and behavioural processes are used to construe the positive actions carried out by the late Queen Mother during her lifetime, activate the minds and emotions of mourners and sympathizers regarding the loss, posthumously project the late Queen Mother as a legend who needs to be modelled after and present a collective purgation of emotions of pain and agony. The study concludes that, despite the apolitical status of traditional rulers, they still have a latent but cordial relationship with politicians.
\end{abstract}

Keywords: systemic functional grammar (SFG); process types; presidential tributes; Nana Afia Kobi Serwaa Apem II; Ashanti Kingdom

Citation: Mwinwelle, P., Duah, I. and Ernest Mensah, S. (2021). Eulogising the Dead: A Systemic Functional Exploration of Tributes Delivered by Ghanaian Presidents. International Journal of Technology and Management Research (IJTMR), Vol. 6 (2): Pp.38-58.

Received: April 15, 2020

Accepted: September 1, 2021 


\subsection{Introduction}

The Akans, the largest ethnic group in Ghana 'believe that when death occurs, mourning is seen as an inevitable and universal human reaction to explain how grievous they are to the loss of someone who is loved and very much appreciated' (Yeboah, 2017). The death of a sitting Queen Mother is one of the greatest losses and an avenue for people to purge their emotions through mourning. The late Queen Mother of the Ashanti Kingdom, Nana Afia Kobi Serwaa Apem II (the deceased), the fifteenth Queen Mother of the kingdom, passed on, on the 14th of November, 2016 at a ripe age of hundred and eleven (111). As Queen Mother of the largest kingdom and one of the most influential ethnic groups in Ghana, individuals as well as institutions expressed their grief and sorrow regarding her demise through the delivery of tributes to eulogize her and also sympathize with the bereaved family and the Ashanti kingdom at large. The sitting president and past living presidents of the country were not left out in the delivery of tributes given the intricate relationship that exists between politicians and traditional rulers. The delivery of tributes can therefore reveal the kind of relationship that exists between eulogists and the deceased. Notwithstanding, there is a deficit in linguistic research on how the delivery of tributes reveals this relationship. In order not to present traditional rulers as politically aligned, politicians usually try to conceal the cordial relationships they have with these traditional rulers. Nonetheless, when death occurs, one cannot but let out their perception and the relationship they had with the deceased. This makes tributes delivered by politicians to traditional rulers a potent linguistic resource for unearthing the latent relationships between politicians and traditional rulers. It is based on this premise that the present study seeks to explore the process types used by Ghanaian presidents to encode various experiences, relationships and thoughts in their tributes delivered to the late Queen Mother of the Ashanti Kingdom. It seeks to identify the dominant transitivity patterns used in funeral tributes delivered by Ghanaian presidents to the late Queen Mother of the Ashanti Kingdom and explore the communicative functions encoded in the identified transitivity patterns.

\subsection{Literature review}

The literature on studies that focus on forms of funeral text types such as death announcement in newspapers (AlAli, 2005; Khatib and Salem, 2011; Afful, 2012; Al-Zubaidi, 2012) and condolence messages (Dilevko \& Gottlib, 2004; Yahya, 2010; Samavarchi and Allami, 2012; Tareq, 2013; Kuang, 2015; Kongo and Gyasi, 2015; Kuang, 2017) are replete. Relative to the copious number of studies on forms of funeral discourse such as death announcement in newspapers and condolence messages is the scanty literature on the linguistic analysis of funeral tributes. The few existing studies on funeral tributes have mainly focused on appraisal resources (Yeboah, 2017; Mohammed and Khudher, 2018), social linguistic resources (Akinyode, 2019), critical discourse analytical resources (Warambo, Odero and Suleh, 2015) and transitivity patterns (Malima, 2015). From the above categorization, it is revealed that little attention has been paid to examining transitivity patterns in funeral tributes. The cardinal aim of this review is therefore to examine works that have analysed the use of linguistic items in funeral tributes to indicate the place of the present study in literature. The empirical review will help draw methodological and theoretical divergence and convergence as well as enable the present study to confirm or contest findings of earlier studies on funeral tributes. 
To start with, Malima (2015) conducted a stylistic exploration of funeral speeches delivered by three heads of states during Nelson Mandela's burial ceremony. The study, framed by the transitivity theory by Halliday (1985), sought to comparatively analyse the use of transitivity patterns and to search for linguistic and extra-linguistic evidence to back the use of such patterns. The findings indicated a preponderant use of material processes to present the positive activities carried out by Nelson Mandela during his lifetime. The other process types such as mental and relational processes were used to unveil good qualities possessed by the deceased.

Secondly, Warambo, Odero and Suleh (2015) critically investigated political undertones and the socioeconomic allusions in the funeral speeches in Kenya using a speech delivered by Junior Odinga during the requiem mass for Fidel Odinga as a case study. This study was underpinned by the Critical Discourse Analytical theory by Fairclough (1995). The study arrived at some important findings. It, first of all, found out that, Fidel, as eulogized, lived in a very harsh socio-political environment, yet he hailed from an economically able family. Again, the study revealed that the deceased had two phases of life contrary to popular beliefs of the political elites in Kenya.

Moreover, Yeboah (2017) studied the appraisal devices employed in published tributes of institutions in some selected Ghanaian newspapers following the demise of the President of the Republic of Ghana, Professor John Evans Atta Mills to show how shocked, and depressed these institutions were on hearing the news of his death. His study was theoretically underpinned by the appraisal strand of the Systemic Functional Linguistics framework. The study examined thirty (30) tributes, fifteen (15) each from both private and public institutions that were published in two Ghanaian Newspapers-Daily Graphic and Ghanaian Times. The information on these tributes was put under three overarching topics which include the acknowledgement of sorrow, sadness and grief. The study showed that the sentiments raised were predominantly revealed in linguistic patterns that showed a negative effect of sadness directed to the wife and the son of the late president, the vice president as well as to the people of Ghana.

Furthermore, Mohammed and Khudher (2018) investigated the discourse of two American tributes by George Bush and Rosalyn Carter using Martin and White's appraisal framework to identify and analyse the resources of attitude that eulogists use to express feelings, judgments and appreciation. Their study revealed that modern eulogies celebrate the deceased's life, unlike early eulogies which focus more on the subject of religion and negative attitudes in a fairly little amount compared with positive attitudinal meanings. The study concluded that eulogists pay more attention to the deceased's character where they tend to use more explicit and positive attributes.

Last but not least, Akinyode (2019) explored the linguistic features employed by Yoruba-English bilinguals to convey emotion for their dead relatives through tributes delivery underpinned by certain sociolinguistic theories such as ethnography, socio-pragmatic and Systemic Functional Grammar theories. The primary source of data comprised 30 audio-visual recorded funeral tribute deliveries by Yoruba-English bilinguals. These 30 funeral tributes consisted of 15 tributes delivered during funeral services of Christian faithful and 15 tributes delivered during funeral services of Muslim faithful. The results showed that the main communicative purpose of funeral tributes among the Yoruba was to praise the dead. It also discovered that certain linguistic features at various levels 
of description; lexical, syntactic, and so on played important roles in fulfilling the communicative purpose of tributes.

From the empirical review above, it can be established that previous studies on the linguistic analysis of funeral tributes have been carried out in countries such as America, South Africa, Nigeria, Kenya and Ghana. In relation to geographical location, it can be established that the study by Yeboah (2017) is similar to the present study since they both employ Ghanaian funeral tributes as their source of data. But while Yeboah (2017) used institutional tributes, the present study is based on tributes delivered by presidents. In terms of the use of a theoretical framework, both the present study and Malima (2015) employed the transitivity framework. The other studies used different theoretical frameworks such as the appraisal theory, critical discourse analytical theory and other sociolinguistic theories. One other distinguishing feature between the studies reviewed and the present study is that the present study employs funeral tributes delivered by politicians to a traditional leader while previous studies analysed funeral tributes delivered by institutions and politicians to other politicians. All the studies reviewed have unanimously established that the delivery of tributes is not just to eulogise the deceased but also directed at assuaging the pain of the bereaved family. The findings of this study will therefore be very useful in that, it will seek to affirm or contest earlier findings in order to contribute significantly to the scanty literature on the linguistic analysis of funeral tributes especially in Ghana and also unveil the kind of relationship that exists between politicians and traditional rulers. The present study is distinct from previous studies in this area as it aims at exploring the transitivity patterns used in funeral tributes delivered by Ghanaian presidents to the late Queen Mother of the Ashanti Kingdom underpinned by the transitivity framework by Halliday and Matthiessen (2014).

\subsection{Theoretical framework}

The Systemic Functional Grammar theory (henceforth SFG) by Halliday and Matthiessen (2014) is a grammatical approach to the study of language that claims that language is a system of choices. It postulates that, for language users to achieve their goals, they make conscious and unconscious use of linguistic forms. This indicates that choosing or neglecting the use of a particular linguistic form has semantic implications. Awuku (2018) further establishes that the factors underpinning the linguistic choices made by language users may include 'their experience of the world in and around them, the topic of discussion and who they may be having the discussion with'. Unlike other structurally oriented grammatical theories, the SFG focuses on how language is used to construe meaning (Halliday and Matthiessen, 2004). SFG theory is sub-categorised into three strands, which are referred to as the three metafunctions. These are the ideational, textual and interpersonal metafunctions. The term Metafunction refers to the ways in which language functions. Textual metafunction provides a correlation between the arrangement of text and the features of the situation in which it is used, the ideational metafunction encodes the expression of the speaker's internal and external experiences while the interpersonal metafunction establishes social relations among interlocutors. The transitivity framework which underpins the present study falls under the ideational metafunction. 


\subsection{Transitivity patterns}

The transitivity framework is a grammatical framework that seeks to detail how speakers encode their experiences in the grammatical choices they make. The framework is made up of various patterns called the transivity patterns or process types which represent different aspects of human experiences. Transitivity patterns (process types) refer to the grammatical and semantic configurations that are used to represent varied forms of human experiences and thoughts in the clause. Halliday and Matthiessen (2014) identify six types of transitivity patterns: material, mental, relational, verbal, behavioural and existential process types. Among these process types, the material, mental and relational process types are considered as the main patterns because they preponderate in texts while verbal, behavioural and existential processes are considered as minor process types. The first transitivity pattern is the material process. It is 'the largest and most diverse category in transitivity' (Thompson, 2014). It is defined by action-driven verbs that describe actions or events. It expresses the notion that some entity does something to some other entity. The actor and the goal are the two important participants in the material process. In some cases, the actor even though may be known but may not be explicitly mentioned in the clause. Anafo (2017) postulates that 'The actor is the entity that performs an action in the clause while the goal is the entity the action performed by an actor affects'. The actor, therefore, initiates the action in the clause while the goal is the participant that receives or is affected by the actions of the actor. Both the actor and goal could be animate or inanimate entities. Ewusi-Mensah (2015) posits that, in the material process, an actor is construed as powerful when its actions affect another entity but as less powerful when its actions do not affect any entity. On the other hand, the affected or goal participants are presented as passive and powerless entities. In essence, the material process may be presented in either the active or passive form to highlight some participants in the clause. Other participants as related to the material processes are the initiator, scope, client, recipient, and attribute (Halliday, 1994).

Another main process type in the transitivity framework is the relational process. This process type construes the varied ways in which a state of being or possession can be expressed through the clause. The relationships expressed in relational processes can be classified into two forms namely, the attributive process and identifying process. Basically, the identifying process determines or unveils an identity while the attributive process assigns a quality to an entity. The attributive relational process consists of two participant roles namely the carrier which refers to the topic of the clause preceding the verb, and attribute, a description of the verb or comment about the topic which usually is adjectival or nominal. On the hand, the identifying relational process encodes the participants; token and value. The token refers to the entity that is identified while the value represents the identifier of the token. Awuku (2018) establishes that a feature that 'differentiates an identifying relational clause from an attributive relational clause is that the former is reversible whereas the latter is not'.

The mental process is also the third main process type in the transitivity system. It refers to the processes of sensing, feeling, thinking and perceiving the things that go on in the internal world of the mind. Mental processes rely on thoughts, observations and sentiments to sense a particular phenomenon. Unlike material processes which encode action-driven outer experiences, mental processes represent a person's inner world or thoughts. The inner thought patterns of speakers are therefore unveiled in the use of verbs that denote processes of thinking or feeling. 
The mental process is made up of two participants which are the sensor and phenomenon. The sensor is not only confined to human beings but can be any object, animate or not, that can be treated as conscious while the phenomenon refers to the entity that is being sensed, felt, or perceived by the sensor. Mental processes can be subcategorized into four main forms namely emotional, cognition, perception and desideration (Halliday and Matthiessen, 2014).

The verbal process as the name suggests refers to the verbalization of the inner thoughts or the manifestation of thoughts in the mind through speech (Mwinwelle, Amoakohene and Agyekum, 2020). In simple terms, the verbal process can be construed as the processes of saying. It has a close relationship with the material and mental processes. The thoughts (mental) which are expected to be carried out through action (material) are rather said or spoken. It aids in the attribution of information to sources. Verbs such as articulate, tell, say, state, communicate, express, etc. are used in verbal processes. The four main participants in the verbal process are the sayer, receiver, target and verbiage. The sayer refers generally to an entity mostly a human entity that exchanges information and meaning through speech or verbal expression. The verbiage refers to the content of the clause or what is said in the clause. The receiver represents the entity to whom the saying is directed or addressed while the target is the entity expected to respond to what is said. In some cases, the target may be the same as the receiver but in other cases, they may differ.

Ewusi-Mensah (2015) explains that 'Behavioural processes represent outer manifestations of inner workings, the acting out of processes of consciousness and physiological states'. They are revealed through physiological and psychological acts in the use of verbs such as breathe, worry, smile, dream, langh, look, taste, listen etc. The verbs in the behavioural process are usually intransitive. These physiological and psychological behaviours in behavioural processes are usually involuntary (Downing and Locke, 2006). Relative to the six process types, the behavioural process is one of the least or minor process types that is partly material and partly mental. It has one principal or obligatory participant called the behaver. The behaver is a conscious entity involved in carrying out a particular behaviour. Two other rare or optional participants in the behavioural process are the behaviour and the phenomenon. The behaviour is a restatement of the behavioural process (Eggins, 2004) while the phenomenon refers to an entity based on whose presence the behaver elicits a particular behaviour.

The last process type in the transitivity system is called the existential process. It represents the processes of existing and happening. It indicates the existence of an entity and sometimes also unveils the location of the existence. It lies between the relational process and the material process. Aside the verb exist, other verbs indicate this process, such as flourish, arise, happen etc. The existential process has a recognizable clausal pattern which normally starts with 'there' or with the verb 'exist' (Halliday, 1994). This process entails only one obligatory participant labelled as Existent. The existent refers to the entity or event which is being said to exist. An Existent can be any kind of phenomenon, such as a thing, person, object, institution or abstraction, action, or event. Another optional participant that rarely occurs in the existential process is the circumstance. The circumstance mainly indicates the location of the existent. 


\subsection{Methodology}

This study is qualitatively descriptive. The data for the study is purposively sampled, which constitutes tributes delivered by sitting and past presidents of Ghana to the late Queen Mother of the Ashanti Kingdom, Nana Afia Kobi Serwaa Apem II (sourced from Pages 27, 37, 38 and 39 of the funeral brochure). These tributes were delivered by Nana Akuffo Addo, Jerry John Rawlings, John Agyekum Kufuor and John Dramani Mahama. The choice of tributes delivered by politicians to the late traditional ruler was considered as data for the study because they would help unravel the latent intricate relationships that exist between traditional rulers and politicians. Halliday and Mathiessien (2014) posit that the meaning of experiences and happenings are expressed through the use of the clause. In this sense, the clauses used in the tributes encode various experiences and thoughts of the speakers which can best be unearthed through the exploration of the transitivity patterns used. The consensual coding strategy was used where each of the researchers independently coded the process types in the tributes and compared them to arrive at the final coded process types which were used in the analysis. Each tribute was coded where Akuffo Addo's tribute was given the code $A A$, Agyekum Kufuor's tribute $J K$, John Mahama's as $J D$ and Jerry John Rawlings' tribute as JJ. Scanned copies of the tributes are attached as an appendix at the end of the study. The analysis of the data was carried out in four phases according to Cohen's (2007) textual analytical model which presents the four stages as: (1). 'Generating natural unit of meaning', (2). 'Classifying, categorizing and ordering these units of meaning', (3). 'Structuring narratives to describe the contents of the text or speech', and (4). 'Interpreting the data'. In the generation of natural units of meaning, each of the tributes was parsed into clauses. Akuffo Addo's tribute contained twenty (20) clauses, Agyekum Kufuor's thirteen (13), John Mahama's twenty-two (22) and Jerry John Rawlings' tribute was made up of thirteen (13) clauses. Secondly, the parsed clauses were further classified and categorised under the various process types in the transitivity system. The identified process types were descriptively structured to advance the discussion of the analysis. Finally, the coded clauses were used as illustrations to back the analysis and based on which, findings, implications, recommendations and conclusions were drawn.

\subsection{Results and discussions}

The first part of the analysis identifies the predominant process types used, followed by the discussion of the communicative functions encoded in the identified process types. The table below presents the process types used by each of the presidents in their tributes with their corresponding frequencies and percentages. 
Table 1: Distribution of process types in the selected Ghanaian presidential tributes

\begin{tabular}{lllllll}
\hline $\begin{array}{l}\text { Process } \\
\text { Types }\end{array}$ & $\begin{array}{l}\text { Akuffo } \\
\text { Addo }\end{array}$ & Mahama & Kufuor & Rawlings & $\begin{array}{l}\text { Total } \\
\text { Frequency }\end{array}$ & $\begin{array}{l}\text { Total } \\
\text { Percentage }\end{array}$ \\
\hline Material & 5 & 7 & 3 & 4 & 19 & $28.0 \%$ \\
Relational & 8 & 7 & 2 & 5 & 22 & $32.4 \%$ \\
Mental & 1 & 5 & 5 & 1 & 12 & $17.6 \%$ \\
Verbal & 6 & 1 & 2 & - & 09 & $13.2 \%$ \\
Behavioural & - & 2 & 1 & 3 & 06 & $8.8 \%$ \\
Total & & & & & 68 & $100 \%$ \\
\hline
\end{tabular}

Table 1 above shows that, relational processes preponderate in the selected tributes. A total of twenty-two (22) relational processes are identified representing $32.4 \%$ of the total number of clauses identified. The second frequent process type is the material process which records a frequency of nineteen (19), representing $28.0 \%$. Mental processes follow with a frequency of twelve (12) representing 17.6\%. Verbal processes record a frequency of nine (9) representing 13.2\% while behavioural processes also record a frequency of six (6) representing $8.8 \%$. The high occurrence of relational processes in the tributes signal that the tributes are more descriptive; describing the life of the late Queen Mother which further reveal the latent relationship between her and the presidents. The predominant use of relational processes to describe positive qualities of the late Queen Mother corroborates the finding from an earlier study on funeral tributes by Mohammed and Khudher (2018) who establish that eulogists pay more attention to the deceased's character where they tend to use more explicit and positive attributes.

\subsection{Analysis of material processes}

To begin with, material processes are used in the tributes to construe the personal actions carried out by the late Queen Mother during her lifetime which portray her as a heroine who is worth eulogizing. In clause [JJ, MAT. CL. 2], Rawlings uses the actor she to refer to the late Queen Mother. The material processes used and protect are used to detail how the late Queen Mother used her position to serve others. The range her position as the mother of the Asanteman indicates the jurisdiction of the power of the late Queen Mother. The use of the goal not only the dignity of womanhood but also the revered and proud position of the Asantehene presents the late Queen Mother as a proactive leader whose power is not only limited to the Ashanti Kingdom but also extends to the general good of womanhood. In [AA, MAT. CL. 1], Akuffo uses the actor Nana Afia Kobi Serwa Apem II, the material process had endorsed with the goal my candidature and the circumstance abead of the December 7, 2016 elections to reveal the contribution of the late Queen Mother in his victory in the 2016 presidential elections. This presents the late Queen Mother as politically aligned to the New Patriotic Party (NPP) in the 2016 general elections. In clause [AA, MAT. CL. 4], the deceased is construed as a victorious fighter through the use of the material processes fought and deserve. In clause [JM, MAT. CL. 3], the material process benefitted is used with the goal My brother, Otumfuo Osei Tutu II, Asantehene and the son of Nana Afia Kobi Serwaa Apem II and I to identify the Asantehene and Mahama as beneficiaries of the deep wisdom exuded by the late Queen Mother. The material clauses below were used to advance the discussion above. 
- She Actor used $\underline{\text { Material }}_{\text {her }}$ hesition as the mother of the Asanteman Range $_{\text {to }}$ to protect Material not only the dignity of womanhood but also the revered and proud position of the Asantehene, Goal ... [JJ, MAT. CL. 2].

- I Actor was campaigning Material in the Nkwanta South Constituency in the Volta Region on October 27, 2016, when I heard the pleasant news Goal that Nana Afia Kobi Serwaa Apem II, had endorsed Material my candidature $\underline{\text { Goal }}$ ahead of the December 7, 2016 elections Sircumstance. [AA, MAT. CL. 1].

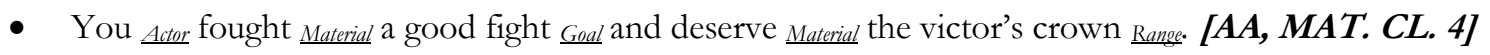

- My brother, Otumfuo Osei Tutu II, Asantehene and the son of Nana Afia Kobi Serwaa Apem II and I

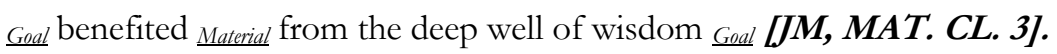

Again, the material clauses in the tributes are used to evoke the blessings of God on the late Queen Mother posthumously. Human goal-oriented clauses are used with the deceased as the goal receiving the blessings from God who is the actor. For instance, in [JM, MAT. CL. G], Mahama uses the actor God, the material process blessed and the goal Maame to attribute the long life lived by the late Queen Mother to the blessings of God. By this gesture, the deceased is presented as one who lived a godly life which attracted the blessings of the lord. In clause [AA, MAT. CL. 5], the actor God is used with the material processes bless and give together with the goal ber soul and the circumstance peaceful rest until the last day of the resurrection to evoke divine blessings on the deceased based on the Christian belief in the resurrection. The request for God's blessings in the tributes confirms Akoto's (2016) assertion that politicians often use biblical allusions at the beginning and end of their speeches to acknowledge that there is an almighty being more powerful than themselves and therefore call upon him for guidance, blessings and protection. The material clauses presented below were used to evidentially support and detail the discussion above.

- ... because God Actor blessed Material Maame Goal to live more than a century on this earth Circumstance. [JM, MAT. CL. 6].

- May God Actor $_{\text {bless }}$ Material her Goal and give Material her soul Goal peaceful rest until the last day of the resurrection $\underline{\text { Gircumstance }}$ when we $\underline{A c t o r}$ shall all meet $\underline{\text { Material }}$ again. Amen! [AA, MAT. CL. 5]

- The year 2016 Actor brought $\underline{\text { Material }}$ many blessings Goal but it also brought $\underline{\text { Material }}$ immense agony Goal because I

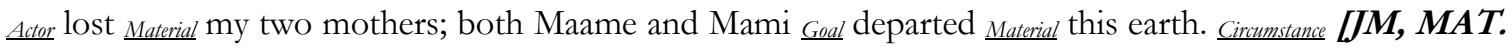
CL. 5].

\subsection{Analysis of relational processes}

The analysis of relational processes is based on only attributive relational processes because instances of the use of identifying relational processes are non-existent in the tributes. The singular past and present forms of the verb be such as was and is are dominantly used in the attributive relational processes to capture the qualities exuded by the late Queen Mother while she was alive which subtly unveils the kind of relationship each of the presidents had with her. To begin with, Rawlings uses relational processes to attribute certain qualities to the late Queen Mother in order to establish a neutral relationship with her. In clauses [JJ, REL. CL. 1] and [JJ, REL. CL. 3] Rawlings uses Nana Afia Kobi as a carrier, the attributive relation process was with the attributes a thoughtful and strong personality and a good-nurtured person. The attributes, a thoughtful and strong personality and a good-nurtured person are attributed to the carrier, Nana Afia Kobi. The late Queen Mother is therefore presented as one who had a good upbringing hence 
her good qualities and values. In [JJ, REL. CL. 4], other attributes perceptive and unwavering are associated with the deceased to present her as one who was focused in life. In [JJ, REL. CL. 5], the deceased is further identified as the secret behind the successful reign of the King of the Ashanti Kingdom who happens to be her son. Rawlings' attribution of various positive qualities to the deceased signals a neutral relationship which does not specify any personal relationship ties with her. The relational clauses presented below were used to back the discussion above.

- Behind the calm and warm demeanour of Nana Afia Kobi Token was Relational a thoughtful and strong personality. Value [JJ, REL. CL. 1]

- She $\underline{T \text { Token }}$ was steeped $\underline{\text { Relational }}$ in tradition. Value [JJ, REL. CL. 2]

- Nana Afia Kobi Carrier was elational (Atrributive) a good-nurtured person Attribute [JJ, REL. CL. 3]

- Nana Afia Kobi Carrier was Relational (Attributive) perceptive and unwavering in her resolve once she had taken a decision Atribute [JJ, REL. CL. 4]

- She Carrier was Relational (Atributive) the silent shadow behind the awesome inspiring role of the Asantehene and her humility, dignity and sense of respect for the stool despite her advanced age and life experiences should serve as a source of inspiration for all. Attribute [JJ, REL. CL. 5]

Secondly, Kufuor uses relational processes to unveil the family lineage of the late Queen Mother to establish kinship ties with her. In clause [JK, REL. CL. 7], Kufour traces and identifies the family lineage of the late Queen Mother through the use of the carrier She, the attributive relational process was and the attributes the daughter of my great-grand ancestor Oheneba Owusu Afriyie, Apagyahene, the son of Otumfuo Osei Kwadwo Okoawria, Asantehene. The use of this attribute signals a kinship tie between Kufuor and the deceased through the use of the possessive personal pronoun $m y$ in the phrase the daughter of my great-grand ancestor... referring to the late Queen Mother. Kufuor, therefore, identifies himself as a matrilineal father or uncle to the deceased. The clause below was used by Kufour to reveal the kinship ties between him and the deceased.

- And this is because historically her great-grand ancestress after whom she carrier was named Relational Nana Afua Kobi, Asantehemaa in the mid-eighteenth-century Attribute was Relational (Attributive) the daughter of my great-grand ancestor Oheneba Owusu Afriyie, Apagyahene, the son of Otumfuo Osei Kwadwo Okoawia, Asantehene. Atrribute [JK, REL. CL. 7]

Moreover, Mahama uses relational processes to establish a foster mother-son relationship with the late Queen Mother. In clause [JM, REL. CL. 8], he uses the carrier Maame Afia Kobi's loss, the relational process is and the attribute a profoundly special one to reveal how the death of the late Queen Mother affected him personally. In clause [JM, REL. CL. 9], he uses the attributes: a mother to my brother and friend, the Asantehene and also my mother to refer to the deceased. Through these attributes, he refers to the son of the deceased, the Asantehene as his brother which builds the background for him to later refer to the deceased as his mother. In JJM, REL. CL. 10], he further uses the attributes my biological mum and also my mother to draw a line of distinction between his biological mother and the deceased although he refers to both of them as his mothers. The clauses below were used by Mahama to unveil the kind of relationship he had with the late Queen Mother.

- Maame Afia Kobi's loss $\underline{\text { Carrier }}$ for me is $\underline{\text { Relational (Atributive) a profoundly special one. Atribute }}$ [JM, REL. CL. 8 ]. 
- She Carrier was Relational (Atributive) not just a mother to all in the Ashanti kingdom; or a mother to my brother and friend, the Asantehene; Atribute Maame carrier was Relational also my mother, one who was full of deep insight and good counsel. Attribute [JM, REL. CL. 9].

- Though Mami Carrier was Relational (Atributive) my biological mum, Attribute Maame token was Relational just as good to me as my own mother $\underline{\text { Value }}$. [JM, REL. CL. 10].

Finally, Akuffo Addo uses relational clauses to indicate the support given him in the 2016 elections by the late Queen mother which establishes a political relationship between him and her. Akuffo Addo in clauses [AA, REL. CL. 18], [AA, REL. CL. 19] and [AA, REL. CL. 22] identifies a political relationship with late Queen Mother through the use of the attributes a formidable supporter of my cause, an invaluable and constant source of advice and prayers for me, and nothing would have given her greater pleasure than to see my success in 2016 and certainly one of those to whom I dedicate my election by Ghanaians to the high office of the President of the Republic. These attributes reveal a latent political relationship between the late Queen Mother and Akuffo Addo. In clause [AA, REL. CL. 17], Akuffo Addo also uses the carrier It, the attributive relational process was and the attribute a day of great sadness for me to construe a circumstantial relationship where the attribute rather refers to time. This identifies the day of the demise of the late Queen Mother as a Memorial Day of sadness for him because he could not thank her for supporting his political activities in the 2016 elections before she passed on. This further deepens the political relationship between the deceased and Akuffo Addo. The attributive relational clauses presented below were used to back the discussion above.

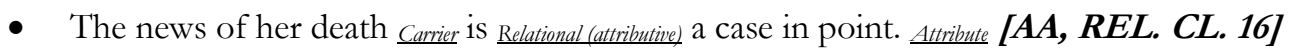

- It Carrier was Relational (Atributive) a day of great sadness for me. Attribute $[\boldsymbol{A A}, \boldsymbol{R E L}$. CL. 17]

- All through the years, she Carrier was Relational (Atributive) a formidable supporter of my cause. Atrribute $[\boldsymbol{A A A}, \boldsymbol{R E L}$.

\section{18]}

- She $\underline{\text { Carrier }}$ was $\underline{\text { Relational (Atributive) }}$ an invaluable and constant source of advice and prayers for me, and nothing would have given her greater pleasure than to see my success in 2016. Atrribute [AA, $\boldsymbol{R E L}$. CL. 19]

- Nana Afia Kobi Serwaa Apem II, thanks for everything. I Carrier am $\underline{\text { Relational (Atrributive) }}$ grateful to Providence that our lives crossed. Atrributive $[A \boldsymbol{A}, \boldsymbol{R E L} . \boldsymbol{C L} .20]$

- She Carrier is Relational (Atrributive) certainly one of those to whom I dedicate my election by Ghanaians to the high office of the President of the Republic. Attribute [AA, REL. CL. 22]

\subsection{Analysis of mental processes}

Mental processes are generally used in the tributes to activate the minds and emotions of the mourners and sympathizers regarding the loss of the late Queen Mother. This activation is realised through the use of mental verbs such as miss, love, remain, remember, believe, know etc. Mahama and Kuffuor made a predominant use of mental processes in their tributes due to the special relationships that they each had with the late Queen Mother to detail how they would miss her cognitively. Kufuor in Clauses [JK, MENT. CL. 1], [JK, MENT. CL. 2], [JK, MENT. CL. 3] and [JK, MENT. CL. 4] uses the sensors I, we, your kingdom and me to indicate how the death of the late Queen Mother would cause a personal and general vacuum in his life and that of the entire Ashanti kingdom while the 
mental processes know, will remain, miss and feel are also used to indicate the depth of knowledge people had about the good qualities of the deceased and the extent to which these good qualities will be missed. Kufuor generally uses mental processes to identify himself as a family relation to the late Queen Mother hence his relatively dominant use of mental processes to reveal this relationship. Also, Mahama in Clauses [JM, MENT. CL. 6], [JM, MENT. CL. 7], [JM, MENT. CL. 8] and [JM, MENT. CL. 9] uses the Sensors I and we together with the mental processes were hopeful, remind, believe and appreciate to detail the unique positive qualities possessed by the late Queen Mother and the cognitive mother-son relationship he had with her which he and her son, the Asantehene were going to miss. The mental clauses below were used to substantiate the discussion above.

- From my infancy, I $\underline{\underline{\text { Senser }}}$ was privileged to know $\underline{\underline{\text { Mental }}}$ Nana $\underline{\text { phenomenon }}$ because of the close friend my mother, Ama Dappah of Apagyafie, had with her. [JK, MENT. CL. 1]

- You phenomenon will remain much-beloved $\underline{\text { Mental }}$ in your kingdom, Asante and by many beyond Sensor $[J K$, MENT. CL. 2].

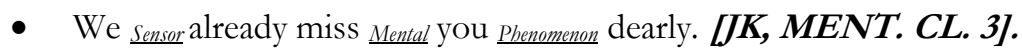

- Nana blessed with exceptional longevity coupled with clarity of mind and memory Circumstance, always

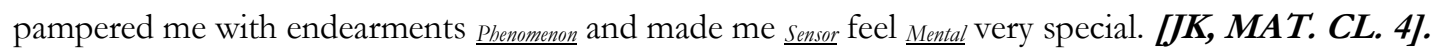

- We $\underline{\text { Sensor }}_{\text {were hopeful }}^{\text {Mental }}$ she could stay a little longer Phenomenon $[J M, M E N T$. CL. 6].

- I Sensor wish to remind $\underline{\text { Mental }}$ us of her unique qualities which include courage, truth, discernment, development-orientedness, wisdom, love and compassion. Phenomenon [JM, MENT. CL. 7]

- That was not to be in her lifetime. But I $\underline{\text { Sensor }}_{\text {believe }}$ Mental that dream can still be kept alive Phenomenon $[J \boldsymbol{M}$, MENT. CL. 8]

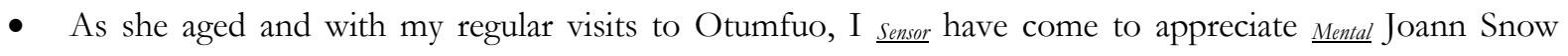
Duncanson's poem “Two Mothers Remembered" even more and in a more personal manner Phenomenon [JM, MENT. CL. 9].

Akuffo Addo and Rawlings on the other hand each made a single use of mental clauses in their tributes. Rawlings in clause [JJ, MENT. CL. 5] uses the sensor Nana Afia Kobi, the mental processes lived to see and witness with the phenomena ascend the throne of the Asante kingdom as Otumfuo and the kind of leadership that made her truly proud. Rawlings presents Nana Afia Kobi as an accomplished mother who lived to see her son ascend the throne as king of such a powerful kingdom as the Ashanti kingdom. This presents her as a virtuous woman who gave her son the best of training which eventually led to his success as king of the Ashanti kingdom. Akuffo Addo in clause $[A A, M E N T$. CL. 11], cognitively, considers the late Queen Mother as the main contributor to his electoral victory in the 2016 general elections through the use of the mental process dedicate. Akuffo Addo therefore posthumously dedicates his electoral victory to the late Queen Mother probably due to the unprecedented number of votes he won in the Ashanti Region which happens to be the region where the Ashanti kingdom is located. The mental clauses below were used to back the discussion above. 
- It is heartwarming that Nana Afia Kobi sensor lived to see Mental her son phenomenon ascend the throne of the Asante kingdom as Otumfuo and witness $\underline{\text { Mental }}$ the kind of leadership that made her truly proud $\underline{\text { Phenomenon }}$ [JJ, MENT. CL. 5].

- She is certainly one of those to whom I $\underline{\text { Sensor }}$ dedicate $_{\underline{\text { Mental }}}$ my election by Ghanaians to the high office of the President of the Republic. Pbenomenon [AA, MENT. CL. 11]

\subsection{Analysis of verbal processes}

Verbal processes are generally used in the tributes to encode various verbal actions in order to posthumously project the late queen mother as a legend who needs to be modelled after. Kufuor uses verbal processes to justify the cordial family relationship between him and the late Queen Mother, as well as present her as one who held the Ashanti tradition in high esteem. Clause [JK, VERB. CL. 1] has four clausal roles: the sayer Nana, the verbal process called, the receiver me, and the verbiage but by the affectionate word "Agya" meaning Father or Daddy. The use of the verbal process called establishes a verbal relationship between the sayer Nana and the target me (Kuffour) which construes a gesture of respect and recognition offered the target (Kufour) by the sayer. Verbal clause [JK, VERB. CL. 2] has three clausal roles namely sayer, verbal process and verbiage. The sayer The Asante belief in reincarnation is metaphorically construed as an animate entity which has the ability to speak through the use of the verbal process should explain together with the verbiage the close bond of relationship Nana graciously extended to Apagyafie. Kufour, therefore, uses the verbal process should explain to present the traditional belief underpinning the existing kinship ties between him and the late Queen Mother. As the sitting president of the country, Akuffo Addo in clauses [AA, VERB. CL. 3], [AA, VERB. CL. 4], [AA, VERB. CL. 5] and [AA, VERB. CL. G] uses the verbal processes express and thank to express his sympathies to the bereaved family and also thank the late Queen Mother posthumously for her role in his election victory in the 2016 general elections. The verbal processes below were used to advance the discussion on the analysis of verbal processes in the tributes.

- Nana sayer always called Verbal me Receiver not by my name, but by the affectionate word "Agya" meaning Father or Daddy Verbiage: [JK, VERB. CL. 1]

- The Asante belief in reincarnation $\underline{\text { Sayer }}_{\text {should explain }}$ serbal_the close bond of relationship Nana graciously extended to Apagyafie. Verbiage [JK, VERB. CL. 2]

- I $\underline{\text { saver }}$ therefore could not wait to get back to the Ashanti region to thank Verbal her Receiver formally for her declaration $\underline{\text { Verbiage: }}:[\boldsymbol{A A}, \boldsymbol{V E R B} . \boldsymbol{C L}$. 3]

- It meant that I $\underline{\underline{\text { sajer }}}$ could not get the opportunity to express $\underline{\text { Verbal }}_{\text {my }}$ sincerest appreciation $\underline{\text { Verbiage }}$ to her Receiver: $[A A, V E R B . C L .4]$

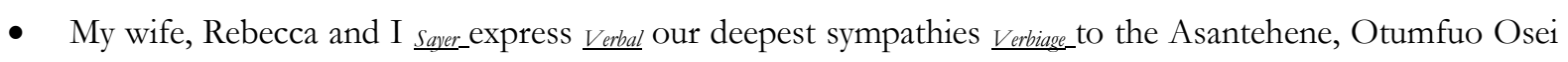
Tutu II, her children, the royal family of Asanteman and to all fellow members of the Oyoko clan on their great loss Receiver [AA, VERB. CL. 5]

- Nana Afia Kobi Serwaa Apem II, Receiver thanks $\underline{V e r b a l}_{\text {for }}$ everything $\underline{V e r b i a g e ~}_{\text {[AA, }}$ VERB. CL. 6]. 


\subsection{Analysis of behavioral processes}

Behavioural processes are used to encode collective purgation of emotions of pain and agony in the tributes. Clause [JM, BEH. CL. 1] is a behavioural clause made up of three clausal roles; the behaver, behavioural process and a circumstance (accompaniment). The clause is made up of the behaver we and the behavioural processes sobbing and mourning and circumstance the loss of our beloved mother, our treasured guardian of ancient wisdom. Mahama uses this behavioural process to reveal his close relationship with Otumfuo which extends to his (Otumfuo) mother, the late Queen Mother. The use of the plural behaver we signals a collective, united and undivided form of mourning which highlights the general effect of the loss since the late Queen Mother was a public figure. The behavioural processes sobbing and mourning are used in the progressive form to indicate a continuous form of mourning to further highlight the depth of the pain and sorrow caused by the loss. The circumstance the loss of our beloved mother, our treasured guardian of ancient wisdom which accompanies the behavioural process in the clause gives an apt description of the unique qualities possessed by the deceased (the late Queen Mother) that justifies the continuous purgation of emotions through sobbing and mourning. Clause [JM, BEH. CL. 2] is also made up of the behavioural processes grieving and celebrating and the phenomenon her precious and royal life. The behavioural processes grieving and celebrating indicate mixed continual emotional reactions created by the loss. The use of grieving as a behavioural process captures the lasting effect of pain that has been caused by the demise hence the continuous emotional reaction of grieving as confirmed by Bernard, Adzei, \& Duhoe (2020) who posit that 'funerals in Ghana are considered as processes and not events... the funeral ceremonies last up to a few days, weeks, months and even a year or more' (p. 59). The use of the process celebrating, also presents the joy that accompanies the demise in that, the late Queen Mother died at an advanced age. She lived over a century dying at the age of one hundred and one (111) years. It is actually very rare to find people live beyond a hundred years and it is, therefore, worth celebrating her since she lived even beyond a hundred years. The discussion of behavioural processes used in the tributes is backed by the behavioural clauses presented below.

- Today, here we $\underline{\text { Behaver }}$ are sobbing and mourning $\underline{\text { Behavioural_ }}$ the loss of our beloved mother, our treasured guardian of ancient wisdom Circumstance phenomenon [JM, BEH. CL. 1].

- On this occasion while grieving and celebrating Behavioural her precious and royal life phenomenon, [JM, $\boldsymbol{B E H}$. CL. 2]

\subsection{Conclusion}

\subsection{Summary of findings and conclusion}

Conclusively, relational, material, verbal, mental and behavioural processes were identified as the process types used in the tributes. The results indicate that among the process types used, relational processes were preponderantly used to identify unique qualities possessed by the late Queen Mother. The attribution of various positive qualities to the deceased through the use of relational processes further established and revealed the latent relationships that existed between her and the presidents who delivered the tributes. In terms of these relationships, Rawlings established a neutral relationship with the late Queen Mother, Kufuor

established kinship ties with her, Mahama established a foster mother-son relationship with her while Akuffo 
Addo established a political relationship with her. Material processes on the other hand were used in the tributes to construe the impact of the positive actions carried out by the deceased during her lifetime. Mental processes such as miss, love, remember, believe, know etc. were dominantly used in the tributes to activate the minds and emotions of mourners and sympathizers. Verbal processes were also employed to posthumously appreciate and project the deceased as a legend who needs to be modelled after while the use of behavioural processes construed a continuous collective purgation of emotions of pain and agony. The study concludes that, despite the apolitical status of traditional rulers, they still have varied latent but cordial relationships with politicians.

\subsection{Implications for theory, research and practice}

The findings of the study have implications for theory, research and practice. In relation to theory, the study makes extensive use of the transitivity theory by Halliday and Matthiessen (2014) to analyse the use of language in funeral discourse. The analytical framework was found very useful as it aided in the identification of various process types in the data. The study confirms the main assumption of the transitivity theory which establishes that material, mental and relational processes are the main process types dominantly used in discourse. Notwithstanding, the findings of the present study regarding the predominant transitivity process types used in funeral tributes contest earlier findings. While Malima (2015) identified the material process as the predominant process type used in funeral tributes, the present study, on the other hand, identifies the relational process type as the dominant process type in the funeral tributes analysed. The predominance of relational processes in the data could be grounded on the premise that the speakers in the tributes used for the present study, dedicated a greater portion of their tributes to outlining the good qualities possessed by the deceased instead of recounting the actions she carried out while alive. This disparity in the finding regarding which process type predominates in funeral tributes could therefore propel future studies to be conducted to synchronize these contrasting findings. Another implication of the study on research is that the study serves as a modest contribution to scholarship on the use of transitivity patterns in Ghanaian funeral tributes since most of the studies on funeral discourse in Ghana have been directed to the analysis of obituaries. Regarding practice, the study has implications for pedagogy and political speechwriters and speakers. For pedagogy, the study like earlier studies has convincingly demonstrated that the clause in the transitivity framework encodes human experiences and actions. The transitivity framework must therefore be considered as a part of the basic grammar at the tertiary level to help students decode various forms of discourse. To politicians in general and presidents in particular, the study establishes that, the choice of linguistic items in communication must consciously represent what the speaker seeks to present and conceal what the speaker wishes to withhold.

\subsection{Recommendations for future research}

The scarcity of linguistic studies on transitivity analysis of funeral tributes underscores the need for further research. The present study, therefore, establishes a solid foundation based on which future studies could 
appropriate the transitivity framework or other linguistic theories to analyse funeral discourse in general. Future studies could employ the transitivity framework or other linguistic theories with a similar or different methodological approach to analyse other forms of funeral discourse such as obituaries, biographical sketches, condolence letters and messages to unearth various communicative implications. To ascertain the influence of cultural backgrounds in the composition of funeral tributes, a contrastive study could be carried out between tributes delivered in different countries or continents. Future research could also focus on the analysis of epistemic modality in funeral tributes to determine the level of doubt or certainty with which tributes are delivered.

\section{References}

. (2017, Jan). The life of Nana Kobi Serwaa Ampem II. [Funeral Brochure]. [Kumasi: University Press, KNUST].

Afful, J. B. A. (2012). Genre analysis of death announcements in Ghanaian newspapers. Language Discourse \& Society, 1 (2), 118-137.

Akinyode, T.O. (2019). Sociolinguistic features of English language usage in funeral tributes by selected Yoruba-English bilinguals in southwestern Nigeria. (MPhil thesis). Obafemi Awolowo University, Ile-Ife, Nigeria.

Akoto, L. (2016). A lexical cohesion analysis of two Ghanaian presidential inaugural speeches: A study of 2001 and 2009 speeches. (MPhil Thesis). University of Education, Winneba, Ghana.

Al- Ali, M. N. (2005). Communicating messages of solidarity, promotion and pride in death announcements genre in Jordanian newspapers. Discourse and Society, 16, 5-31.

Al-Khatib M., Salem Z. (2011). Obituary announcements in Jordanian and British Newspapers: A cross-cultural overview. Acta Linguistica.

Al-Zubaidi N. (2012). Expressions of Gratitude in American English and Iraqi Arabic: Interlanguage and Cross-Cultural Perspectives. Germany: Lambert Academic Publishing.

Anafo, C. (2018). The language of deception: Transitivity analysis of scam email messages. (M.Phil. Thesis). University of Education, Winneba, Ghana.

Awuku, B.O. (2018). Agency and processes in religious discourse: A transitivity analysis of the Sermon on the Mount. (M.Phil. Thesis). University of Ghana, Legon.

Bernard, T. A., Adzei, M., \& Duhoe, A. A. A. (2020). The irony in funeral of two religious sects in Ghana: A comparative study in Islam and Christianity. Research Journal in Advanced Humanities, 1(3), 58-71. Retrieved from https://royalliteglobal.com/advanced-humanities/article/view/164.

Cohen, L (2007). Research Methods in Education. London: Routledge.

Dilevko, J. \& Gottlieb, L. (2004). The portrayal of librarians in obituaries at the end of the twentieth century. Library Quarterly, 74 (2), 152-180.

Downing, A., \& Locke, P. (2006). English grammar: A University Course. New York, NY: Routledge.

Egenti, M.C. and Mmadike, B.I. (2016). Speech act analysis of Igbo utterances in funeral rites. Ogirisi: A New Journal of African Studies. 12, 46-67. http://dx.doi.org/10.4314/og.v12i 1.3.

Eggins, S. (2004). An Introduction to Systemic Functional Linguistics. London: Biddles Ltd. 
Ewusi-Mensah, L. (2015). Transitivity in political discourse: the 2009 state-of-the-nation address in Ghana. (MPhil Thesis). University of Education, Winneba, Ghana.

Fairclough, N. (1995). Critical Discourse Analysis. London: Longman.

Halliday, M. A. K. (1985). An Introduction to Functional Grammar. London: Edward Arnold.

Halliday, M. A. K. (1994). An Introduction to Functional Grammar (2nd ed.). London: Hodder Arnold.

Halliday, M. A. K., \& Matthiessen, C. M. I. M. (2004). Halliday's Introduction to Functional Grammar, (3rd ed.). London $\&$ New York: Routledge.

Halliday, M. A. K., \& Matthiessen, C. M. I. M. (2014). Halliday's Introduction to Functional Grammar, (4th ed.). London \& New York: Routledge.

Harris, J. W. (2007). Remembrances and celebrations: A book of eulogies, elegies, letters and epitaphs. New York, NY: The Guilford Press.

Kongo, A. E., and Gyasi, K.W. (2015). Expressing grief through messages of condolence: A genre analysis. African Journal of Applied Research. 2(2), 61-71.

Kuang, C. H. (2015). Functions of Malaysian condolences written in text messages. Social Sciences \& Humanities Journal. 23 (1), 1-19.

Kuang, C. H. (2017). Features of language in Facebook condolence messages. International Journal of English Research. $3(5), 22-30$.

Malima, M.J. (2015). A stylistic analysis of state funeral speeches a case study of Nelson Mandela's burial ceremony. (Master of Arts thesis). University of Dares Salaam.

Mohammed, M.M. and Khudher, S.H. (2018). Appraisal perspective on attitudinal meaning in eulogies for Ronald Reagan and Betty Ford. Journal of Basra Research for Human Sciences. 43(1), 1-22.

Mwinwelle, P., Amoakohene, B. and Agyekum, O. N. (2020). Creating institutional solidarity: A transitivity analysis of anthems of selected Ghanaian universities. Advances in Language and Literary Studies. 11(2), 74-83. http://dx.doi.org/10.7575/aiac.alls.v.11n.2-p.74

Samavarchi, L., \& Allami, H. (2012). Giving condolences by Persian EFL learners: A contrastive socio-pragmatic study. International Journal of English Linguistics, 2(1), 71-78.

Stevens, H. (2008). How to Plan a Funeral: Your Complete Guide to Funeral Services and Savings. United States: Cemetery Sport, Inc.

Tareq, M. M. (2013). May Allah not let you experience another sorrow: Condolence strategies used by lecturers who are native speakers of Arabic L1 toward their colleague who is native speaker of Hebrew in Hebrew L2. Theory and Practice in Language Studies, 3(3), 17-22.

Thompson, G. (2014). Introducing Functional Grammar. London: Routledge.

Warambo, J.P., Odero, E.O. and Suleh, E. (2015). A critical discourse analysis of funeral speeches in Kenya: A case of Junior Odinga's speech. Research on Humanities and Social Sciences. 5(4), 1-6.

Yahya, E. M. (2010). A study of condolences in Iraqi Arabic with reference to English. Adab AlRafidayn, 57, 47-70.

Yeboah, N.A. (2017). Expressing grief through institutional tributes: An appraisal theory approach. Language in India. 17(12), 401-408. 


\section{APPENDIX}

\section{$\ldots . A(0), \cdot$. \\ HIS EXCELLENCY NANA ADDO \\ DANKWA AKUFO-ADDO \\ President, Republic of Ghana}

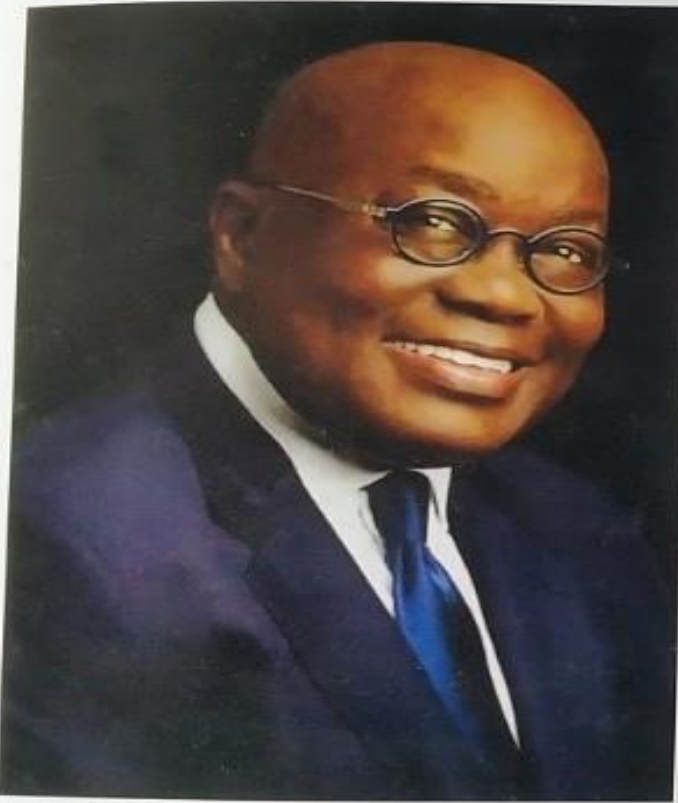

I

was campaigning in the Nkwanta South constituency in the Volta Region on October 27, 2016, when I heard the pleasant news that the Asantehemaa, Nana Afia Kobi Serwaa Ampem II, had endorsed my candidature ahead of the December 7, 2016 elections. This was great news for my campaign. The strength of her character, the respect accorded by Asanteman, and the Ghanaian people at large, meant that a significant boost had been given to my campaign. 1, therefore, could not wait to get back to the Ashanti Region to thank her formally for her declaration.

It has often been said that man proposes and God disposes. The news of her death is a case in point. It meant that I could not get the opportunity to express my sincerest appreciation to her. Nearly three weeks after her declaration, at the ripe old age of 111 , God called her home on $14^{\text {th }}$ November, 2016. It was a day of great sadness for me.

All through the years, she was a formidable supporter of my cause. She was an invaluable and constant source of advice and prayers for me, and nothing would have given her greater pleasure than to see my success in 2016. She is certainly one of those to whom I dedicate my election by the Ghanaian people to the high office of President of the Republic.

My wife, Rebecca, and I extend our deepest sympathies to the Asantehene, Otumfuo Osei Tutu II, her children, the royal family of Asanteman and to all fellow members of the Oyoko clan on their great loss.

Nana Afia Kobi Serwaa Ampem II, thanks for everything. I am grateful to Providence that our lives crossed. You fought a good fig'ht, and deserve the victor's crown. Yours was a life welllived.

May God bless her and give her soul peaceful rest until the last day of the Resurrection when we shall all meet again. Amen! 


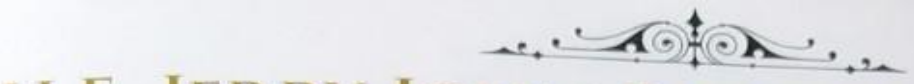 \\ H.E. JERRY JOHN RAWLINGS \& NANA KONADU AGYEMAN-RAWLINGS \\ FORMER PRESIDENT AND FORMER FIRST LADY, REPUBLIC OF GHANA}
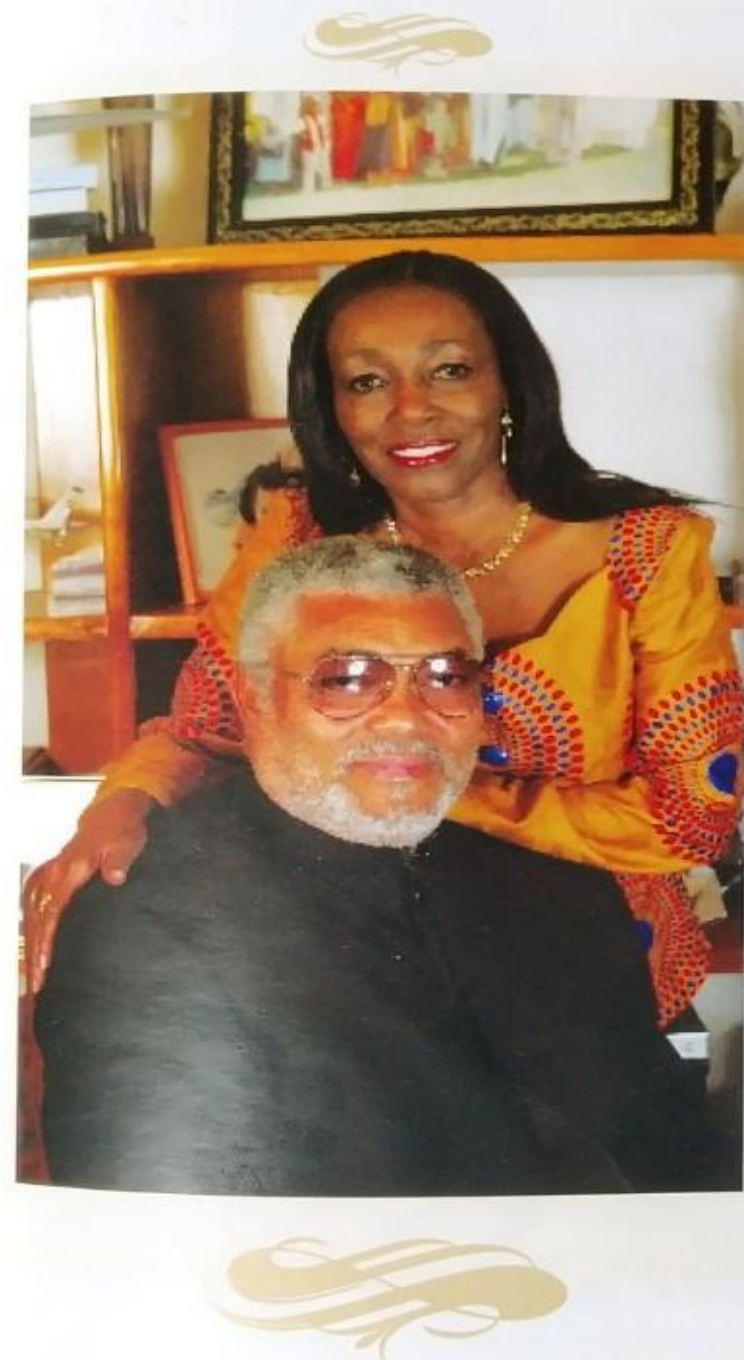

A santeman has lost a great and legendary mother. Behind the calm and warm demeanour of Nana Afia Kobi was a thoughtful and strong personality who was steeped in tradition and who endeavoured to pass on her brand of true Asante discipline and resilience to all she interfaced with.

Nana Afia Kobi was a good-natured person who used her position as mother of Asanteman to protect not only the dignity of womanhood, but also the revered and proud position of the Asantehene, right from our departed Nana Opoku Ware II to her son, Nana Osei Tutu II.

Nana Afia Kobi was perceptive and unwavering in her resolve once she had taken a decision. That trait endeared her to many and gained her utmost respect amongst all who had the good fortune to meet her.

She was the silent shadow behind the aweinspiringrole of the Asanteheneandher humility, dignity and sense of respect for the stool despite her advanced age and life experiences should serve as a source of inspiration for all.

It is heartwarming that Nana Afia Kobi lived to see his son ascend the throne of the Asante Kingdom as Otumfuo and witness the kind of leadership that made her truly proud.

Damirifa due Otumfuo Osei Tutu II

Damirifa due Asanteman!

Nantie yie, Nana Afia Kobi! 


\section{H.E. JOHN DRAMANI MAHAMA \\ Former President, Republic of Ghana}

The great American writer, Henry Sydney Porter captured the essence of life in his pronouncement that "life is made of smiles, sniffles and sobs..."

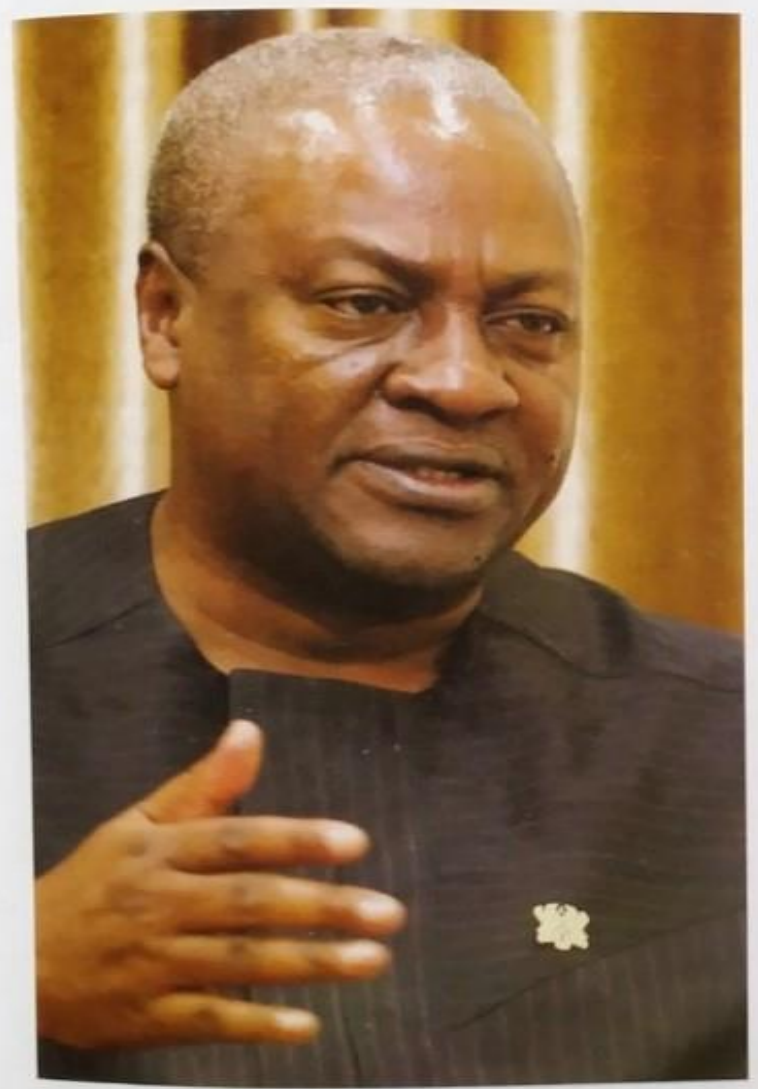

A nd indeed, throughout our transient life's journey on this earth, we have gone through the cycle of smiling, of sniffling and of sobbing. Was it not just yesterday, we all shared joyous moments with our mother? Today, here we are sobbing and mourning the loss of our beloved mother, our treasured guardian of ancient wisdom.

Maame Afia Kobi's loss for me is a profoundly personal one. She was not just a mother to all in the Ashanti Kingdom; or a mother to my brother and friend the Asantehene; Maame was also my mother, one who was full of deep insight and good counsel.
My brother Otumfuo Nana Osei Tutu II, Asantehene and a son of Nana Afia Kobi Serwaa Ampem II and I benefited from her deep well of wisdom. Even though Maame was aging and fading away with the passage of time, we were hopeful she could stay a little longer. Just a little longer. But this was not to be.

The year 2016 brought many blessings, but it also brought immense agony because I lost my two mothers; both Maame and Mami departed this earth. Though Mami was my biological mum, Maame Afua Kobi was just as good to me as my own mother. And she lived her life to the fullest because God blessed Maame to live more than a centenary on this earth.

As I write this tribute I am mindful of her status as the thirteenth $\left(13^{\text {th }}\right)$ Queen mother of the Ashanti Kingdom. On this occasion whiles grieving and celebrating her precious and royal life, I wish to remind us of her unique qualities which includes courage, truth, discernment, development-orientedness, wisdom, love and compassion.

She was concerned, not just about Asanteman. Ghana was first on her mind because she believed the success of the nation was key to the greater success of Asanteman. It was my intension to name the Kumasi Central Market after her; as a sign of our appreciation and love for her enormous contribution to the development of our nation. That was not to be in her lifetime. But I believe that dream can still be kept alive.

As she aged and with my regular visits to Otumfuo, I have come to appreciate Joann Snow Duncanson's poem "Two Mothers Remembered" even more and in a more personal manner. That is how it begins and ends as God wills it.

Maame Damirifa due!

Maame da yie!! 


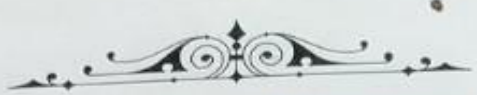 \\ H.E. JOHN AGYEKUM KUFUOR \\ Former President, Republic of Ghana}

\section{Nana, Blessed one of God, Damirifa due, Oyoko Kronkron Baatan, Damirifa due, Due ne amane hunu.}

$\mathrm{F}$ rom my infancy, I was privileged to know Nana because of the close friendship my mother, Ama Dapaah of Apagyafie, had with her.

Nana always called me not by my name, but by the affectionate word "Agya", meaning Father or Daddy. And this is because historically her great- grand ancestress after whom she was named Nana Afua Kobi,Asantehemaa in the mid-eighteeth centry, was the daughter of my great-grand ancestor Oheneba Owusu Afriyie,Apagyahene, the son of Otumfuo Osei Kwadwo Okoawia, Asanthene.

The Asante belief in reincarnation should explain the close bond of relationship Nana graciously extended to Apagyafie. Thankfully, her son Otumfuo Osei Tutu II and his entire royal family continue to sustain this favour towards Apagya.

Nana, blessed with exceptional longevity coupled with clarity of mind and memory, always pampered me with endearments and made me feel very special.

Nana you very successfully fulfilled your historic role of destiny. You will remain much beloved in your Kingdom, Asante, and by many beyond who were fortunate to come close to you. We already miss you dearly.

Rest in Peace, Nana.

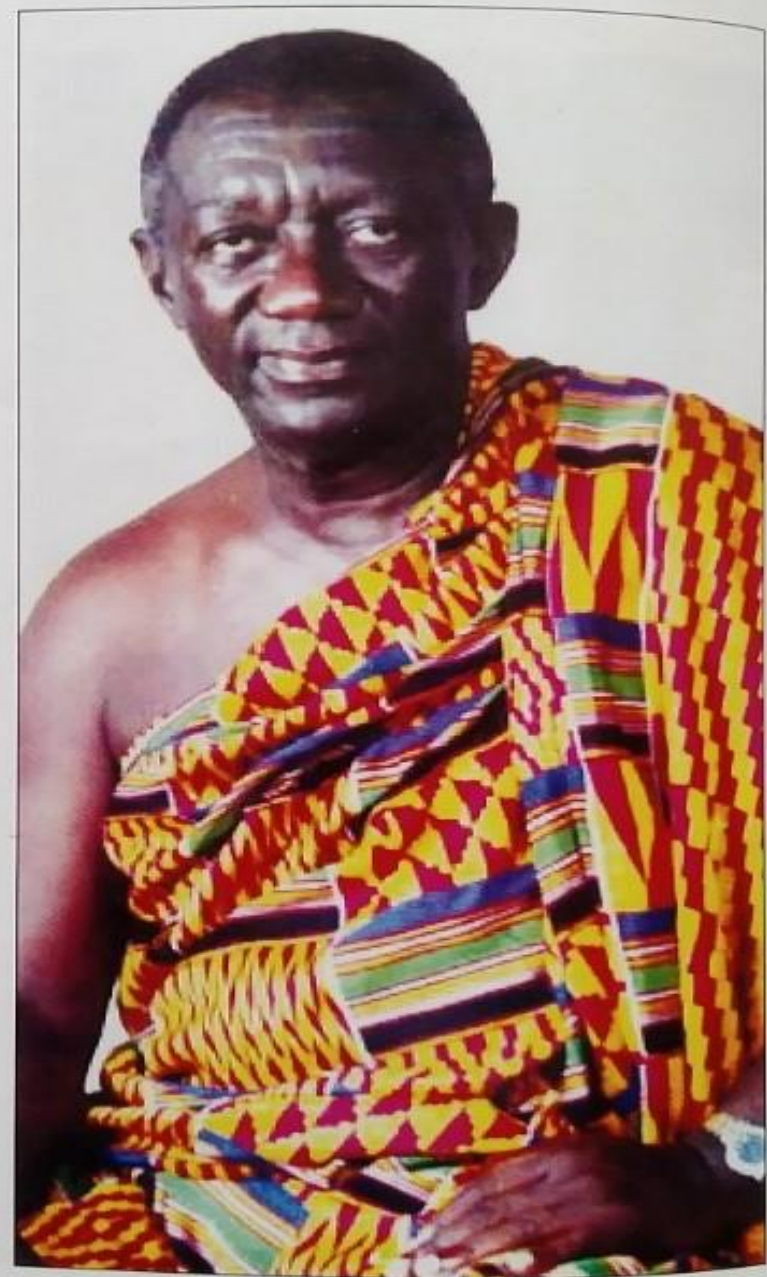

